\title{
Anti-Abortion Law is an Ethical Issue, Thanks for Alabama Governor Kay Ivey
}

\author{
Othman Alfleesy* \\ Department of Forensic Medicine, Aden University, South Yemen
}

*Corresponding author: Othman Alfleesy, Associate Professor of Forensic Medicine, Department of Forensic Medicine and Pathology, Faculty of Medicine and Health Sciences, Aden University, Aden, South Yemen.

To Cite This Article: Othman Alfleesy. Anti-Abortion Law is an Ethical Issue, Thanks for Alabama Governor Kay Ivey. Am J Biomed Sci \& Res. 2019 - 3(5). AJBSR.MS.ID.000714. DOI: 10.34297/AJBSR.2019.03.000714

Received: July 03, 2019 | Published: July 05, 2019

\section{Editorial}

Michael Cook the editor of Bio Edge published an article on 19 May 2019, titled: Alabama passes most restrictive abortion law in US, which seems to me one of the most important issue for human life. On the basis of this important article let me say:

The good soul is driven by good motives and loving living feelings and Governor Kay Ivey was that one. Your courageous step in making this immortal, courageous, moral and ethical decision is a real and tangible expression of your humanity, your living conscience, your high morals, and the principles of your ethics, education and behaviour, regardless of social or political altercation dilemmas.

All American citizens with all their political affiliations, their parties, their loyalties, their gatherings, their unions, their institutions and their positions at home, must be proud and work to support this courageous decision that protects and preserves the life of a living soul for persons in their wombs from deliberate and irresponsible killing and murder. This decision is supported by all the heavenly religions and all faiths in all over the earth which deny the assault on the lives of others.

When the soul is breathed into a human after creating inside the womb it is forbidden to kill it or to tamper with it by any means. This decision is blessed by God, whatever your religion and faith. This historical decision up to date does not have any similar one in any Arabic or Islamic country in the world, although we are required to issue law like it. It is well known saying says: A fair (Just) non-Islamic state is better (more fair) to God than an unjust Islamic state. I do not mean that America is a just state, but in this matter it is indeed.

We bless and congratulate you Governor Kay Ivey (Governor of Alabama) and raise the hat in respect to you. you lastly responded to the call of conscience and the call of the French scientist Dr. Jerome

Lejeune and support the fighting of Mr. David Lejeune, President of JLF USA, who defends for Down syndrome rights and life and the appeal of Dr. Othman alfleesy to Down syndrome children mothers [1-3]. These are the ethics that rise and rise and live to remain after the death of a person. This immortal decision will remind you to future generations because it is in the interest of the citizen and women including mothers and respect their humanity, faith and raising their morals. Be indifferent and do not care to the oppressors and those who claim right privacy in order to kill weak humans. You will inevitably prevail as long as your intention is sincere to this matter.

Go on Governor Kay and do not care to those who chirps outside the bird's squadron. Thus, we say that there are good people on earth regardless of their affiliations and beliefs. I challenge all the ministers of health in the Arab and Islamic countries to affirm that there are decisions issued in their countries similar to this text other than (loose criminal abortions act). No Islamic country have passed law similar to this law with its accurate terms (before heartbeat, at 6th week). Still there are abortions in Islamic states for fetuses more than 20 weeks.

I call to hold a world conference, to be organized by WHO in which all the countries of the world will take part to discuss this issue and its main point and axis and is the decision of Alabama Governor antiabortion law.

\section{References}

1. Othman alfleesy (2018) Why Do They (abort) Down Syndrome Fetus inside the Womb? Journal of Genetic Disorders 2: 1-4.

2. Othman Alfleesy (2018) Why Mothers are not responsible for Down Syndrome Children? CPQ Cancer 3(3): 12.

3. Othman Alfleesy (2019) Why Mothers have not responded to my First appeal in regard to Down Syndrome Fetuses Abortion. Int Jr Pediatric \& Child Care 1(2): 1-2. 